\title{
PENGARUH PENGGUNAAN POLLARD TERFERMENTASI DENGAN RAGI TAPE DALAM RANSUM TERHADAP PRODUKSI TELUR AYAM LOHMANN BROWN
}

\author{
BIDURA, I G. N. G., PUSPANI, E., WARMADEWI, D. A., SUSILA, T. G. O., \\ DAN SUDIASTRA, I W. \\ PROGRAM STUDI PETERNAKAN, FAKULTAS PETERNAKAN, UNIVERSITAS UDAYANA \\ Jl. PB. Soedirman, Denpasar Bali \\ e-mail: bidura_unud@yahoo.com
}

\begin{abstract}
ABSTRAK
Penelitian ini bertujuan untuk mempelajari pengaruh penggunaan pollard terfermentasi oleh ragi tape terhadap produksi telur ayam Lohmann Brown umur 42-50 minggu. Rancangan yang digunakan adalah rancangan acak lengkap (RAL) dengan tiga perlakuan dan enam kali ulangan dan setiap ulangan menggunakan dua ekor ayam Lohman Brown umur 42 minggu. Ransum yang digunakan selama penelitian mengandung protein kasar $17 \%$ dan energi metabolis $2750 \mathrm{kkal} / \mathrm{kg}$. Ransum tanpa pollard (A) sebagai ransum kontrol, ransum dengan penggunaan 15\% pollard (B), dan ransum dengan 15\% pollard terfermentasi oleh ragi (C). Ransum dan air minum diberikan ad libitum. Variabel yang diamati, yaitu konsumsi ransum, berat telur total, berat telur rata-rata, jumlah telur, tebal kulit telur, berat jenis, warna kuning telur, efisiensi penggunaan ransum, dan kadar kolesterol telur. Hasil penelitian menunjukkan bahwa penggunaan $15 \%$ pollard terfermentasi oleh ragi (perlakuan C) ternyata tidak berpengaruh nyata $(\mathrm{P}>0,05)$ terhadap konsumsi ransum, berat telur, hen-day production, warna kuning telur, dan FCR dibandingkan dengan kontrol. Sebaliknya, secara nyata $(\mathrm{P}<0,05)$ menurunkan kadar kolesterol telur ayam. Penggunaan $15 \%$ pollard ternyata secara nyata $(\mathrm{P}<0,05)$ meningkatkan konsumsi ransum. Akan tetapi secara nyata $(\mathrm{P}<0,05)$ menurunkan efisiensi penggunaan ransum, hen-day production, dan tebal kulit telur dibandingkan dengan kontrol. Dari hasil penelitian ini dapat disimpulkan bahwa penggunaan $15 \%$ pollard dalam ransum ternyata menurunkan produksi telur, dan sebaliknya setelah mengalami fermentasi oleh ragi tape nyata memberikan hasil yang sama dengan kontrol serta mampu menurunkan kadar kolesterol telur ayam Lohmann Brown umur 42-50 minggu.
\end{abstract}

Kata kunci : ragi tape, pollard, kolesterol telur, efisiensi penggunaan ransum

\section{EFFECT OF POLLARD FERMENTED BY YEAST CULTURE IN DIETS TO EGG PRODUCTION OF LOHMANN BROWN EGGS}

\begin{abstract}
This research was carried out to study the effect of pollard fermented by yeast culture in diets to egg production and cholesterol contents of Lohmann Brown (42-50 weeks of age). Three treatments were used in a completely randomized design (CRD). Each treatment consisting of six replications with two birds (42 weeks of age in equal weight) per replication. The eight weeks experimental diets for the laying period (42-50 weeks of age) were formulated with $17 \%$ crude protein and $2750 \mathrm{kcal} \mathrm{ME} / \mathrm{kg}$ as a control diet (A), diets with $15 \%$ pollard (B), and diets with $15 \%$ pollard fermented by yeast culture (C), repectively. Diets and drinking water were provided ad libitum during the experimental period. The results showed that $15 \%$ use of pollard fermented by yeast culture in diets were not significantly different on feed consumption, egg weight, hen-day production, egg yolk colour, and feed efficiencies compared to control groups $(\mathrm{P}>0.05)$. In contrast, these significantly decreased cholesterol content of eggs $(\mathrm{P}<0.05)$. The use of diets with $15 \%$ pollard significantly increased feed consumption compared to control groups $(\mathrm{P}<0.05)$. However, these could decrease feed efficiency, hen-day production, and shell thickness of eggs compared to control group $(\mathrm{P}<0.05)$. It can be concluded that use of $15 \%$ pollard in diets decreased the egg production, whereas using pollard fermented by yeast culture gave similar effect to control and decreased of cholesterol contents of Lohmann Brown eggs (42-50 weeks of age).
\end{abstract}

Key words: yeast culture, pollard, egg cholesterol, feed efficiency 


\section{PENDAHULUAN}

Pollard merupakan bahan pakan alternatif yang mengandung potensi besar, baik sebagai sumber energi, sumber serat kasar, ataupun sumber makro nutrien lainnya. Faktor pembatas penggunaannya dalam ransum adalah tingginya kandungan serat kasar dari limbah tersebut, karena ternak unggas tidak dapat mencerna serat kasar. Akan tetapi, kehadiran serat kasar di dalam ransum sangat essensial sekali artinya karena serat kasar mempunyai fungsi fisiologis dan fungsi nutrisi bagi ternak unggas (Siri et al., l992). Pernyataan ini didukung oleh Sutardi (1997) yang menyatakan bahwa pertumbuhan usus dan sekum dapat dirangsang oleh serat.

Kecuali potensinya sebagai sumber energi, kandungan serat kasar pada pollard mempunyai keunggulan dalam menekan kadar kolesterol dan akumulasi lemak tubuh pada ternak unggas (Bidura, 2007). Serat kasar yang tinggi dalam ransum dapat mengurangi absorpsi lemak, sehingga deposisi lemak dan kadar kolesterol produk dapat ditekan serta dapat meningkatkan retensi mineral copper dan besi (Basyir, 1999), meningkatkan densitas volume epitel dan vilus usus halus (Lundin et al., 1993).

Upaya meningkatkan nilai guna pollard tersebut dapat dilakukan dengan memanfaatkan kemampuan dari khamir Saccharomyces cereviseae, yaitu mikroba atau khamir utama yang terkandung di dalam ragi tape (Bidura, 2012). Dilaporkan juga bahwa Saccharomyces cereviseae dapat berperan sebagai probiotik pada unggas, dapat meningkatkan nilai nutrisi dedak padi, dan dapat menurunkan kandungan kolesterol dalam darah.

Selain cara tersebut di atas (ragi yang ditambahkan ke dalam ransum), maka yang mungkin menarik perlu dikaji khasiatnya adalah pemanfaatan ragi sebagai inokulan fermentasi, sehingga ragi dapat berfungsi ganda yaitu sebagai sumber sumber probiotik dan sebagai mikroba pemecah senyawa kompleks pada pollard. Hasil penelitian menunjukkan bahwa penggunaan 0,20\% ragi tape sebagai inokulan fermentasi dedak padi, nyata dapat meningkatkan kecernaan dedak padi dan penampilan itik (Bidura et al., 2009). Dilaporkan juga oleh Widiyanto et al. (1994), pada saat difermentasi oleh T. virideae, maka kandungan serat kasar ransum dapat didegradasi, sehingga dapat dimanfaatkan oleh ternak unggas. Khasiat lain dari produk fermentasi dilaporkan oleh Tanaka et al. (1992), ternyata dapat menekan aktivitas enzim 3-hydroxy-3-methylglutaryl Co-A reduktase yang berfungsi untuk mensintesis kolesterol dalam hati. Penggunaan produk fermentasi dalam ransum nyata menurunkan jumlah lemak tubuh itik (Bidura, 2008).
Beberapa hasil penelitian pendahuluan mengenai penggunaan ragi dalam ransum ternyata mampu meningkatkan penampilan, nilai guna pakan serat, dan menurunkan perlemakan tubuh unggas. Candraasih dan Bidura (2001) melaporkan bahwa penggunaan 0,50\% ragi pada ransum yang mengandung $15 \%$ cangkang coklat nyata dapat meningkatkan pertambahan berat badan itik. Demikian juga halnya dengan suplementasi ragi pada serbuk gergaji kayu dapat menurunkan jumlah lemak subkutan termasuk kulit karkas (Ariana dan Bidura, 2001). Abdulrahim et al. (1996) melaporkan bahwa penggunaan probiotik dalam ransum nyata dapat menurunkan kandungan kolesterol telur.

Dari uraian tersebut di atas, perlu kiranya dilakukan penelitian yang bertujuan untuk mengetahui pengaruh penggunaan pollard terfermentasi oleh ragi tape terhadap produksi telur ayam Lohmann Brown umur 42-50 minggu.

\section{MATERI DAN METODE}

\section{Tempat dan Lama Penelitian}

Penelitian di laksanakan di kandang milik petani peternak di Banjar Bakisan, Desa Denbantas, Tabanan, Bali, sedangkan analisis laboratorium dilaksanakan di Laboratorium Teknologi Hasil Ternak, Fakultas Peternakan, Universitas Udayana, Denpasar. Penelitian berlangsung selama delapan bulan, yaitu mulai dari persiapan sampai dengan penyusunan laporan.

\section{Kandang dan Ayam}

Kandang yang digunakan adalah kandang dengan sistem battery colony dari bilah bambu sebanyak 18 buah. Tiap petak kandang berukuran panjang $0,50 \mathrm{~m}$, lebar o,40 m, dan tinggi o,40 m. Semua petak kandang terletak dalam sebuah bangunan kandang dengan atap genteng dan sudah dilengkapi dengan tempat pakan dan air minum.

Ayam yang digunakan adalah ayam petelur Lohmann Brown umur 42 minggu yang diperoleh dari petani peternak ayam petelur di daerah Tabanan dengan berat badan hampir sama.

\section{Ransum dan air Minum}

Ransum yang digunakan dalam penelitian ini dihitung berdasarkan tabel komposisi zat makanan menurut Scott et al. (1982), dengan menggunakan bahan seperti: jagung kuning, tepung ikan, bungkil kelapa, dedak padi, kulit gandum, kulit kacang kedelai, garam, dan premix. Semua perlakuan ransum disusun isokalori (ME: 2750 kcal/kg) dan isoprotein (CP: 17\%). Air minum yang diberikan bersumber dari perusahan air minum setempat. 
Tabel 1. Komposisi Bahan dalam Ransum Ayam Petelur Umur 42-50 Minggu

\begin{tabular}{lrrr}
\hline \multirow{2}{*}{ Bahan (\%) } & \multicolumn{3}{c}{ Perlakuan } \\
\cline { 2 - 4 } & \multicolumn{1}{c}{ A } & \multicolumn{1}{c}{ C } & \multicolumn{1}{c}{ D } \\
\hline Jagung kuning & 55,03 & 50,04 & 50,04 \\
Tepung ikan & 13,30 & 13,63 & 13,73 \\
Bungkil kelapa & 5,56 & 3,56 & 3,56 \\
Dedak Padi & 14,67 & 3,48 & 3,28 \\
Kac. Kedele & 4,28 & 4,28 & 3,68 \\
Kulit kerang & 6,55 & 6,35 & 6,42 \\
Pollard & - & 15,00 & $\left.15,00^{*}\right)$ \\
Minyak kelapa & 0,31 & 3,36 & 3,49 \\
Ragi & - & - & 0,10 \\
Premix & 0,30 & 0,30 & 0,30 \\
Total & 100 & 100 & 100 \\
\hline
\end{tabular}

Keterangan:

*): Pollard sebelum dicampurkan ke dalam ransum dengan bahan pakan lainnya, terlebih dahulu difermentasi dengan 0,20\% ragi tape yang dilarutkan kedalam 1 liter larutan molasses

Tabel 2. Komposisi Zat Makanan dalam Ransum Ayam Petelur Umur 42-50 Minggu

\begin{tabular}{lrcccc}
\hline \multirow{2}{*}{ Komposisi } & \multicolumn{5}{c}{ Perlakuan $^{1)}$} \\
\cline { 2 - 6 } & & $\mathrm{A}$ & $\mathrm{C}$ & $\mathrm{D}$ & Standar $^{1)}$ \\
\hline ME & $\begin{array}{r}\text { (kkal/ } \\
\text { kg) }\end{array}$ & 2750 & 2750 & 2750 & 2750 \\
Protein kasar & $(\%)$ & 17 & 17 & 17 & 17 \\
Eter Ekstrak & $(\%)$ & 6,43 & 8,07 & 8,07 & $5-10$ \\
Serat Kasar & $(\%)$ & 4,04 & 7,25 & 7,25 & $3-8$ \\
Ca & $(\%)$ & 3,57 & 3,55 & 3,55 & 3,70 \\
P-tersedia & $(\%)$ & 0,63 & 0,64 & 0,64 & 0,45 \\
Arginin & $(\%)$ & 1,28 & 1,20 & 1,20 & 0,85 \\
Lysin & $(\%)$ & 1,21 & 1,21 & 1,22 & 0,73 \\
Metionin & $(\%)$ & 0,42 & 0,39 & 0,40 & 0,30 \\
Triftopan & $(\%)$ & 0,18 & 0,18 & 0,18 & 0,17 \\
Iso-leusin & $(\%)$ & 0,84 & 0,81 & 0,82 & 0,68 \\
Leusin & $(\%)$ & 1,64 & 1,52 & 1,53 & 1,32 \\
Penilalanin & $(\%)$ & 0,85 & 0,78 & 0,79 & 0,78 \\
Valin & $(\%)$ & 0,92 & 0,85 & 0,86 & 0,68 \\
Treonin & $(\%)$ & 0,76 & 0,71 & 0,72 & 0,68 \\
Histidin & $(\%)$ & 0,43 & 0,38 & 0,38 & 0,34 \\
\hline
\end{tabular}

Keterangan :

1) Standar Scott et al. (1982)

\section{Ragi Tape}

Saccharomyces cerevisieae. Saccharomyces cerevisieae bersumber dari ragi tape yang umumnya digunakan dalam pembuatan tape merk "Na Kok Liong", terdaftar nomor 26895 yang diperoleh dari pasar umum setempat.

\section{Fermentasi Pollard}

Pollard sebelum dicampurkan ke dalam ransum dengan bahan pakan lainnya, terlebih dahulu difermentasi dengan $0,20 \%$ ragi tape yang dilarutkan ke dalam 1 liter larutan molasses. Selanjutnya larutan tersebut disiramkan ke dalam pollard sampai kadar air $\pm 35 \%$ (bila dikepal tidak pecah). Selanjutnya dimasukkan ke dalam kantung plastik warna hitam, ditutup rapat, dan disimpan selama tiga hari. Hasil penelitian pendahuluan menunjukkan bahwa setelah difermentasi, kandungan protein pollard meningkat dari 16,05\% menjadi 20,19\% dan serat kasarnya menurun dari 16,2 \% menjadi $13,48 \%$.

\section{Pemberian Ransum dan Air Minum}

Ransum perlakuan dan air minum diberikan ad libitum sepanjang periode penelitian. Penambahan ransum dilakukan 2-3 kali sehari dan diusahakan tempat ransum terisi 3/4 bagian, untuk mencegah agar ransum tidak tercecer.

\section{Rancangan Percobaan}

Rancangan yang dipergunakan dalam penelitian ini adalah rancangan acak lengkap (RAL) dengan tiga macam perlakuan dan enam kali ulangan. Tiap ulangan (unit percobaan) menggunakan 2 ekor ayam petelur Lohman Brown umur 42 minggu dengan berat badan homogen. Ke tiga perlakuan yang dicobakan adalah :

- Ransum basal tanpa penggunaan pollard sebagai kontrol (A)

- Ransum dengan penggunaan $15 \%$ pollard tanpa fermentasi (B)

- Ransum dengan 15\% pollard fermentasi dengan ragi tape (C)

\section{Variabel yang Diamati}

Variabel yang diamati atau di ukur dalam penelitian ini adalah:

1. Konsumsi ransum: konsumsi ransum diukur setiap dua minggu sekali, yaitu selisih antara jumlah ransum yang diberikan dengan sisa ransum.

2. Jumlah telur dan berat telur: pengamatan dan penimbangan dilakukan setiap hari dengan menggunakan timbangan kepekaan o,10 gram.

3. Feed Conversion Ratio (FCR) untuk telur: merupakan perbandingan antara jumlah ransum yang dikonsumsi dengan berat telur. Merupakan tolok ukur untuk menilai tingkat efisiensi penggunaan ransum. Semakin rendah nilai FCR, semakin tinggi efisiensi penggunaan ransumnya, demikian sebaliknya.

4. Kadar kolesterol telur: analisis kimia dengan menggunakan satu butir telur pada akhir penelitian pada masing-masing ulangan (unit percobaan). Analisis kolesterol dengan menggunakan metode Lieberman-Burchad. Larutan sterol dalam kloroform direaksikan dengan asam asetat anhidrat sulfat pekat. Dalam uji ini dihasilkan warna dari hijau kebiruan sampai warna hijau, tergantung kadar kolesterol sampel. Larutan yang dihasilkan tertera pada spektrofotometer untuk mendapatkan densitas optik 
Tabel 3. Pengaruh Pemberian Kulit Gandum dengan dan Tanpa Terfermentasi dengan Ragi terhadap Produksi dan Kadar Kolesterol Telur Ayam Lohmann Brown Umur 42-50 Minggu

\begin{tabular}{lcccc}
\hline \multirow{2}{*}{ Variabel } & \multicolumn{3}{c}{ Perlakuan $^{1)}$} & \multirow{2}{*}{ SEM $^{2)}$} \\
\cline { 2 - 4 } & $\mathrm{A}$ & $\mathrm{B}$ & $\mathrm{C}$ & \\
\hline Konsumsi ransum (g/ & $8647,34 \mathrm{~b}^{3)}$ & $9895,79 \mathrm{a}$ & $8695,70 \mathrm{~b}$ & 158,06 \\
ekor/8 minggu) & & & & \\
Berat telur total (g) & $287,87 \mathrm{a}$ & $2795,42 \mathrm{~b}$ & $2977,98 \mathrm{a}$ & 30,614 \\
FCR $^{4}$ & $3,01 \mathrm{~b}$ & $3,54 \mathrm{a}$ & $2,92 \mathrm{~b}$ & 0,835 \\
Rataan berat telur (g) & $58,12 \mathrm{a}$ & $58,25 \mathrm{a}$ & $59,04 \mathrm{a}$ & 1,097 \\
Jumlah telur (butir) & $49,43 \mathrm{a}$ & $47,99 \mathrm{~b}$ & $50,44 \mathrm{a}$ & 0,309 \\
Hen-day production (\%) & $88,35 \mathrm{a}$ & $85,70 \mathrm{~b}$ & $90,08 \mathrm{a}$ & 0,609 \\
Tebal kulit telur (mm) & $0,385 \mathrm{a}$ & $0,370 \mathrm{a}$ & $0,395 \mathrm{a}$ & 0,005 \\
Warna kuning (1-15) & $8,90 \mathrm{a}$ & $8,97 \mathrm{a}$ & $8,89 \mathrm{a}$ & 0,508 \\
Kolesterol (mg/100 g) & $487,08 \mathrm{a}$ & $500,36 \mathrm{a}$ & $458,42 \mathrm{~b}$ & 2,093 \\
\hline
\end{tabular}

Keterangan :

1) Ransum basal tanpa ragi sebagai kontrol (A), ransum dengan $15 \%$ pollard (B), dan $15 \%$ pollard terfermentasi dengan $0,20 \%$ ragi (C).

2) Standard Error of the treatment means

3) Nilai dengan huruf yang berbeda pada baris yang sama, berbeda nyata $(P<0,05)$

4) Feed conversion Ratio = konsumsi ransum/berat telur total

(DO). Hasil tersebut kemudian dibandingkan dengan DO dari larutan standar, sehingga dapat dihitung besarnya kadar kolesterol sampel (Plummer, 1977).

\section{Analisis Statistika}

Data yang diperoleh dianalisis dengan sidik ragam dan apabila terdapat perbedaan yang nyata $(\mathrm{P}<0,05)$ di antara perlakuan, maka dilanjutkan dengan uji jarak berganda dari Duncan (Steel and Torrie, 1989).

\section{HASIL DAN PEMBAHASAN}

Jumlah ransum yang dikonsumsi selama delapan minggu penelitian pada ayam yang diberi ransum tanpa pollard sebagai kontrol adalah $8647,34 \mathrm{~g} / \mathrm{ekor} / 8 \mathrm{ming}-$ gu (Tabel 3). Rataan jumlah ransum yang dikonsumsi oleh ayam yang diberi ransum dengan $15 \%$ pollard (B) adalah: $14,43 \%$ nyata $(\mathrm{P}<0,05)$ lebih tinggi daripada kontrol (A). Hal ini disebabkan karena penggunaan pakan serat tersebut (pollard) di dalam ransum menyebabkan peningkatan kandungan serat kasar ransum. Peningkatan kandungan serat kasar menyebabkan laju aliran ransum dalam saluran pencernaan ayam meningkat (Bidura et al., 2010). Kandungan serat kasar dalam ransum yang tinggi menyebabkan ada sebagian fraksi energi netto yang hilang untuk aktivitas tambahan gizard, serta untuk gerak peristaltik usus untuk mendorong serat kasar keluar saluran pencernaan (Lloyd et al., 1978), sebagai akibatnya ayam akan meningkatkan konsumsi ransum untuk pemenuhan akan energi. Peningkatan konsumsi ransum akan diikuti dengan peningkatan konsumsi zat makanan lainnya, seperti serat kasar dan protein.

Akan tetapi, setelah pollard tersebut mengalami fermentasi oleh ragi (perlakuan C) ternyata konsumsi ransum tidak menunjukkan perbedaan yang nyata $(\mathrm{P}>0,05)$ dengan kontrol. Hal ini disebabkan karena proses fermentasi menyebabkan kecernaan serat kasar dan zat makanan lainnya mengalami peningkatan (Bidura et al., 2008).

Penggunaan $15 \%$ kulit gandum (pollard) tanpa terfermentasi ternyata menurunkan produksi telur sebesar $2,91 \%$ nyata $(\mathrm{P}<0,05)$ lebih rendah daripada kontrol. Akan tetapi setelah pollard mengalami fermentasi dengan ragi (perlakuan $\mathrm{C}$ ) produksi telurnya mengalami peningkatan sebesar $5,11 \%$ nyata $(\mathrm{P}<0,05)$ lebih tinggi dibandingkan dengan perlakuan B. Demikian juga halnya dengan berat telur total pada ayam yang mendapat perlakuan $\mathrm{C}$ adalah $6.53 \%$ nyata $(\mathrm{P}<0,05)$ lebih tinggi dibandingkan dengan ayam perlakuan B. Tebal kulit telur dan nilai warna kning telur ketiga perlakuan tidak menunjukkan adanya perbedaan yang nyata $(\mathrm{P}>0,05)$.

Proses fermentasi pollard dengan ragi tape ternyata dapat meningkatkan produksi telur (hen-day production) dan berat telur. Hal ini disebabkan karena dengan adanya ragi sebagai inokulan fermentasi pollard akan bekerja sebagai fermenter (peragi) bahan organik. Hasil peragian bahan organik tersebut adalah berupa pelepasan asam amino dan sakarida dalam bentuk senyawa organik terlarut yang mudah diserap. Melalui proses peragian tersebut dihasilkan asam organik, hormon, vitamin, dan antibiotik. Senyawa yang dihasilkan ini akan sangat bermanfaat sekali untuk produksi telur. Hasil penelitian ini didukung Suryani dan Bidura (1999), bahwa suplementasi $0,50 \%$ ragi dalam ransum dapat meningkatkan produksi telur dan efisiensi penggunaan ransum. Disamping itu, ragi sebagai sumber probiotik dalam ransum nyata dapat meningkatkan retensi mineral kalsium, fosfor, dan mangan (Piao et al., l999) yang sangat erat sekali kaitannya dalam proses pembentukkan kulit telur.

Disamping itu, peningkatan tersebut dapat juga diakibatkan karena meningkatnya konsumsi ransum dan zat makanan lainnya, seperti protein dan zat warna kuning telur yang banyak terdapat pada jagung kuning (xhantophyl). Peningkatan konsumsi protein dapat meningkatkan berat telur. Disamping itu, konsumsi serat kasar yang meningkat menyebabkan kecernaan dan retensi nitrogen meningkat (Siri et al., 1992). Dilaporkan juga oleh Yalcin et al. (1990), bahwa penggunaan kulit kacang hazel sampai tingkat 6\% ternyata secara nyata meningkatkan warna kuning dan berat telur telur. Peningkatan konsumsi ransum, maka secara logis jagung kuning yang terkonsumsi juga meningkat. Jagung kuning banyak mengandung xantophyl dan B-caroten, yang menyebabkan warna kuning telur meningkat. Bidura et al. (2009) menyatakan bahwa penggunaan pollard terfermentasi oleh ragi tape dapat meningkatkan kecernaan protein dan serat kasar pollard tersebut. 
Apabila produk pollard terfermentasi tersebut diberikan pada itik, secara nyata meningkatkan pertambahan berat badan dan efisiensi penggunaan ransumnya.

Feed conversion ratio (FCR) merupakan salah satu indikator yang dapat memberikan gambaran tentang tingkat efisiensi penggunaan ransum. Semakin rendah nilai FCR, maka semakin tinggi tingkat efisiensi penggunaan ransumnya. Penggunaan $15 \%$ pollard terfermentasi oleh ragi tape yang juga berfungsi sebagai sumber probiotik dalam ransum secara nyata $(\mathrm{P}<0,05)$ dapat meningkatkan efisiensi penggunaan ransum. Hal ini dimungkinkan karena keberadaan probiotik dalam ransum dapat meningkatkan aktivitas enzimatis, meningkatkan aktivitas pencernaan (Jin et al., l997), meningkatkan kecernaan ransum, kecernaan protein, dan mineral fosfor (Piao et al., l999). Disamping itu, probiotik itu sendiri bertindak sebagai penyedia protein sel tunggal yang mempunyai nilai gizi tinggi khususnya sebagai penyedia asam amino essensial yang sangat diperlukan sekali dalam sintesis telur. Meningkatnya efisiensi penggunaan ransum dengan adanya proses fermentasi oleh ragi disebabkan karena dalam ragi tape terkandung khamir Saccharomyces spp yang dapat mendegradasi serat kasar dan meningkatkan kandungan protein dalam bahan pakan (Bidura et al., 2012)

Penggunaan $15 \%$ pollard terfermentasi oleh ragi tape dalam ransum secara nyata $(\mathrm{P}<0,05)$ dapat menurunkan kandungan kolesterol telur. Kadar kolesterol total pada telur ayam perlakuan $\mathrm{C}$ nyata $(\mathrm{P}<0,05)$ sebesar $8,38 \%$ lebih rendah dibandingkan dengan telur ayam perlakuan B. Kandungan kolesterol telur menurun dengan adanya produk fermentasi ragi dalam ransum. Menurut Linder (1985), kurang lebih 25-40\% kolesterol yang dibutuhkan oleh tubuh berasal dari makanan dan selebihnya dari endogenus (biosintesis) terutama di dalam hati. Dilaporkan juga bahwa kalau kolesterol terkonsumsi dan terserap kurang, maka lebih banyak yang disintesis oleh hati dan sebaliknya. Adanya suplementasi ragi dalam ransum ternyata dapat menurunkan kadar kolesterol telur. Abdulrahim et al. (1996) malaporkan bahwa suplementasi probiotik di dalam ransum dapat menurunkan kadar kolesterol serum darah dan telur ayam. Dilaporkan juga oleh Suryani dan Bidura (1999) bahwa suplementasi ragi tape dalam ransum rasionil ternyata dapat menurunkan kadar kolesterol telur ayam. Penambahan probiotik dalam ransum ternyata dapat menekan kadar kolesterol plasma darah itik (Bidura et al., 2012). Dilaporkan juga oleh Bidura dan Suwidjayana (2000), bahwa suplementasi probiotik dalam ransum berserat nyata dapat menurunkan kandungan kolesterol telur ayam. Disamping probiotik, tingginya kandungan serat kasar dalam ransum juga dapat menurunkan kandungan kolesterol dalam telur (Bidura et al., 1996).
Dari hasil penelitian ini dapat disimpulkan bahwa penggunaan $15 \%$ pollard terfermentasi oleh ragi tape (Saccharomyces cereviseae) dalam ransum ternyata dapat meningkatkan produksi telur dan menurunkan kandungan kolesterol dalam telur ayam Lohmann Brown umur 42-50 minggu.

\section{UCAPAN TERIMAKASIH}

Pada kesempatan ini penulis mengucapkan terimakasih kepada Rektor Universitas Udayana dan Ketua Lembaga Penelitian Unud, atas dana yang diberikan melalui penelitian Dana DIPA (PNBP) Unud, sehingga penelitian dan penyusunan tulisan ilmiah ini dapat terlaksana. Ucapan terimakasih penulis sampaikan pula kepada Bapak Gusti Ketut Astika atas peminjaman kandang dan kerjasamanya selama penelitian.

\section{DAFTAR PUSTAKA}

Abdulrahim, S.M., Haddadin, M.S.Y., Haslamoun, E.A.R. and. Robinson, R.K. 1996. The Influence of Lactobacillus acidhophilus and Bacitracin on Layer Performance of Chickens and Cholesterol Content of Plasma and Egg Yolk. British Poult. Sci. 37: 341-346.

Ariana, I N.T. dan Bidura, I G.N.G. 2001. Bobot dan Komposisi Fisik Karkas Ayam Broiler yang Diberi Ransum dengan Penambahan Serbuk gergaji Kayu, Ragi Tape dan Kombinasinya. Majalah Ilmiah Peternakan 4 (1): $21-26$

Bidura, I G.N.G., Warmadewi, D.A., Candrawati, D.P.M.A., Aryani, I G.A.I., Putri Utami, I. A., Partama, I.B.G. and Astuti, D.A.. 2009. The effect of ragi tape fermentation products in diets on nutrients digestibility and growth performance of Bali drake. Proceeding. The $1^{\text {st }}$ International Seminar on Animal Industry 2009. Sustainable Animal Production for Food Security and Safety. 2324 November 2009. Faculty of Animal Science, Bogor Agricultural University. Pp:180-187

Bidura, I G.N.G., Warmadewi, D.A., dan Candrawati , D.P.M.A. 2010. Pakan Unggas, Konvensional dan Inkonvensional. Udayana University Press, Denpasar

Bidura, I G.N.G., Udayana, I D.G.A, Suasta, I M. dan Yadnya, T.G.B. 1996. Pengaruh Tingkat Serat Kasar Ransum terhadap Produksi dan Kadar Kolesterol Telur Ayam. Laporan Penelitian. Fakultas Peternakan, Unud., Denpasar

Bidura, I G.N.G. dan Suwidjayana, I N. 2000. Pemanfaatan Pod Kakao yang Disuplementasi Probiotik dalam Ransum terhadap Produksi dan Kadar Kolesterol Telur Ayam. Laporan Penelitian Dosen Muda. Ditbinlitabmas, Dikti, Fakultas Peternakan, Unud, Denpasar.

Bidura, I G.N.G., Susila, T.G.O., dan Partama, I.B.G. 2008. Limbah, Pakan Ternak Alternatif. Udayana University Press, Denpasar

Bidura, I G.N.G., Mahardika, I G., Suyadnya, I P., Partama, I.B.G., Oka, I.G.L., Candrawati, D.P.M.A. and Aryani, I G.A. 2012. The implementation of Saccharomyces 
spp.n-2 isolate culture (isolation from traditional yeast culture) for improving feed quality and performance of male bali ducking. Agricultural Science Research Journal. September: Vol. 2 (9): 486-492

Candraasih, N.N.K. dan Bidura, I G.N.G. 2001. Pengaruh Penggunaan Cangkang Kakao yang Disuplementasi Ragi Tape dalam Ransum terhadap Penampilan Itik Bali. Majalah Ilmiah Peternakan 4 (3): 67-72.

Jin, L. Z., Ho, Y.W., Abdullah, N. and Jalaludin, S. 1997. Probiotics in Poultry: Modes of Action. Worlds Poultry Sci. J. 53 (4): $351-368$

Linder, M.C. 1985. Biokimia Nutrisi dan Metabolisme. Ed. II. Penterjemah A. Parakkasi. Penerbit UI., Jakarta.

Lloyd, L. E., McDonald, B. E. and Crampton, E. W.. 1978. The Carbohidrates and Their Metabolism. In: Fundamental of Nutrition. $2^{\text {nd }}$ Ed. W.H. Freman and Co., San Francisco.

Piao, X. S., Han, I. K., Kim, J. H., Cho, W. T., Kim, Y. H., and Liang, C. 1999. Effects of Kemzyme, Phytase, and Yeast Supplementation on the Growth Performance and Pul- lution Reduction of Broiler Chicks. Asian-Aust. J.Anim. Sci. 12 (1): 36 - 41

Plummer, D.T. 1977. An Introduction to Practical Biochemestry. McGraw-Hill Book Co., Ltd. New Delhi.

Scott, M. L., Neisheim, M. C. and Young, R. J. 1982. Nutrition of the Chickens. 2nd Ed. Publishing by: M.L. Scott and Assoc. Ithaca, New York.

Siri, S., Tobioka, H. and Tasaki, I.. 1992. Effects of Dietary Cellulose Level on Nutrient Utilization in Chickens. AJAS 5 (4): 741-746.

Steel, R. G. D. and Torrie, J. H.. 1989. Principles and Procedures of Statistics. 2nd Ed. McGraw-Hill International Book Co., London.

Suryani, N.N. dan Bidura I G.N.G. 1999. Pengaruh Penambahan Ragi Tape dalam Ransum terhadap Produksi Telur Ayam Lohmann Brown. Majalah Ilmiah Peternakan. Fapet Unud. 2 (1): 10-14.

Yalcin, S., I. Colpan and Sehu, A. 1990. The Utilization of Hazelnut Hulls by Laying Hens. Vet. Fakultesi-Dergisi, Univ. Ankara 37 (3): 485-498 